\title{
The Central Role of Metal Coordination in Selenium Antioxidant Activity
}

\author{
Erin E. Battin, Nathan R. Perron, and Julia L. Brumaghim* \\ Department of Chemistry, Clemson University, Clemson, SC 29634-0973
}

SUPPORTING INFORMATION

\section{Experimental details}

General. Water was purified using a Barnstead Nanopure DIamond system. $\mathrm{CuSO}_{4} \cdot 5$ $\mathrm{H}_{2} \mathrm{O}$, ascorbic acid, and $\mathrm{H}_{2} \mathrm{O}_{2}$ (30 \% solution) were purchased from Fisher Scientific; $\mathrm{NaCl}$ (99.999\%) and absolute ethanol were purchased from Aldrich; selenium compounds were purchased from Acros. The absorption spectra were measured on a Shimadzu UV-3101PC spectrophotometer in water at $\mathrm{pH}$ 7. Plasmid DNA (pBBSK) was purified by a Qiaprep spin plasmid miniprep kit (Qiagen, Chatsworth, MA). The purified DNA was eluted in TE buffer and dialyzed at $4{ }^{\circ} \mathrm{C}$ against $130 \mathrm{mM} \mathrm{NaCl}$ for 24 h to remove metal ions.

DNA nicking experiments. The indicated concentration of selenium compound, $\mathrm{CuSO}_{4}$ (4 $\mu \mathrm{M})$, ascorbic acid $(5 \mu \mathrm{M})$, ethanol $(100 \%, 10 \mathrm{mM})$, and $130 \mathrm{mM} \mathrm{NaCl}$ at $\mathrm{pH} 7$ were combined and allowed to stand at room temperature for 5 min. Plasmid DNA (pBSSK, 0.1 pmol in $130 \mathrm{mM} \mathrm{NaCl}$ ) was then added and the reaction mixture was allowed to stand for an additional 5 min prior to $\mathrm{H}_{2} \mathrm{O}_{2}(50 \mu \mathrm{M})$ addition. After $30 \mathrm{~min}$, EDTA (50 $\left.\mu \mathrm{M}\right)$ was added. All concentrations indicated are the final concentrations in a $10 \mu \mathrm{L}$ reaction volume. The nicked and supercoiled forms of the plasmid were separated by electrophoresis on a $1 \%$ agarose gel in TAE buffer (140 V for $30 \mathrm{~min}$ ). The gels were stained with ethidium bromide and imaged under UV light, and the percentage of nicked and supercoiled DNA was quantified using UVIproMW (Jencons Scientific Inc., Bridgeville, PA, 2003). Ethidium stains supercoiled DNA less efficiently than nicked DNA, so supercoiled DNA band intensities were multiplied by 1.24 prior to comparison. Intensities of the nicked and supercoiled bands were normalized for each lane so that $\%$ nicked $+\%$ supercoiled $=100 \%$. For gels run using $\mathrm{Cu}(\text { bipy })_{2}{ }^{2+}$ (bipy $=$ bipyridine) as the copper source, a similar procedure was used, substituting $\mathrm{Cu}$ (bipy) ${ }_{2}{ }^{2+}(50 \mu \mathrm{M})$ for the $\mathrm{CuSO}_{4}$ and increasing the ascorbic acid concentration to $63 \mu \mathrm{M}$.

Calculation of percent DNA damage inhibition. Percent DNA damage inhibition was determined using the formula $1-[\% \mathrm{~N} / \% \mathrm{~B}] * 100$, where $\% \mathrm{~N}=$ percentage of nicked DNA in the selenium-containing lanes (Lanes 6-10) and \%B = percentage of nicked DNA in the $\mathrm{Cu}^{+} / \mathrm{H}_{2} \mathrm{O}_{2}$ lane (Lane 5). All percentages are corrected for residual nicked DNA (nicked DNA observed in Lane 2) prior to calculation. Results are the average of at least three trials, and standard deviations are indicated in Tables S1-S5) as well as by error bars in Figure 3.

Glutathione peroxidase measurements. Glutathione peroxidase (GPx) measurements were performed by monitoring the formation of $\mathrm{PhSSPh}$ from $\mathrm{PhSH}$ according to the procedure outlined by Mareque et al. ${ }^{1}$ using stock solutions of the selenium compounds in methanol (2aminophenyl diselenide, selenomethionine) or water (selenocystine, selenomethionine), depending on solubility of the compound. Initial rates were determined as the average of at least four trials and are reported relative to selenomethionine as measured in the appropriate solvent. 
UV-vis measurements. Aqueous solutions of $\mathrm{CuSO}_{4}$ and ascorbic acid were combined and the $\mathrm{pH}$ was adjusted to 7 with $\mathrm{NaOH}(1 \mathrm{M})$. An aqueous solution of the selenium compound was then added to give the final concentrations listed in Figures 4, S5, and S6. Addition of the selenium compounds to solutions of ascorbic acid resulted in no new absorbances in the UV-vis spectra (data not shown).

\section{Supporting Results}

Gel electrophoresis results for selenomethionine and 2-aminophenyl diselenide. Gel electrophoresis experiments of the inhibition of DNA damage by selenomethionine and 2aminophenyl diselenide are shown in Figures S1 and S2. Tabulated values for the bands observed in the gel electrophoresis experiments are given in Tables S1-S5. Since selenomethionine also showed the ability to inhibit DNA damage inhibition, gels were run with $\mathrm{Cu}$ (bipy) ${ }_{2}{ }^{+}$as the copper source. A gel showing the lack of inhibition of DNA damage with selenomethionine and $\mathrm{Cu}(\text { bipy })_{2}{ }^{+}$is shown in Figure S3.

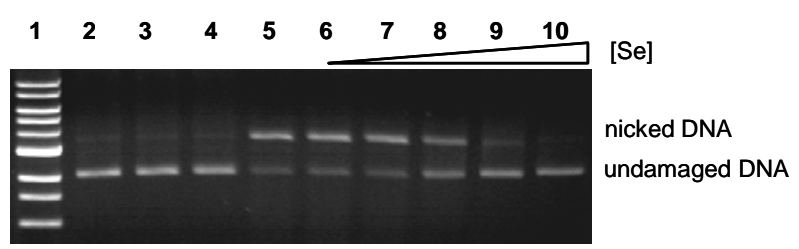

Figure S1. Agarose gel showing reduction in oxidative DNA damage with the addition of $\mathrm{Cu}^{2+}$ /ascorbic acid, $\mathrm{H}_{2} \mathrm{O}_{2}$, and selenomethionine (Se). Lanes: 1) $1 \mathrm{~kb}$ ladder; 2) plasmid DNA; 3) DNA $+\mathrm{H}_{2} \mathrm{O}_{2}$; 4) DNA $+\mathrm{Se}+\mathrm{H}_{2} \mathrm{O}_{2}$, 5) DNA $+\mathrm{Cu}^{2+} /$ ascorbic acid $+\mathrm{H}_{2} \mathrm{O}_{2}$; 6-10) same as lane 5 with increasing [Se]: $0.1,1,10,100$ and $1000 \mu \mathrm{M}$, respectively.

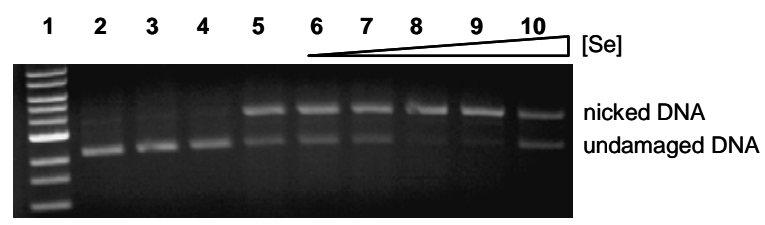

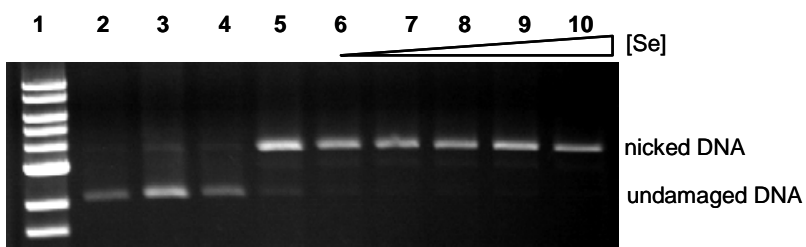

Figure S2. Agarose gel showing reduction in oxidative DNA damage with the addition of $\mathrm{Cu}^{2+}$ /ascorbic acid, $\mathrm{H}_{2} \mathrm{O}_{2}$, and 2-aminophenyl diselenide (Se). Lanes: 1) $1 \mathrm{~kb}$ ladder; 2) plasmid DNA; 3) DNA $+\mathrm{H}_{2} \mathrm{O}_{2}$; 4) DNA + Se $+\mathrm{H}_{2} \mathrm{O}_{2}$, 5) DNA $+\mathrm{Cu}^{2+} /$ ascorbic acid $+\mathrm{H}_{2} \mathrm{O}_{2}$; 6-10) same as lane 5 with increasing [Se]: 0.001, 0.1,1,10, and $25 \mu \mathrm{M}$, respectively.

Figure S3. Agarose gel with $\mathrm{Cu}(\text { bipy })_{2}{ }^{2+}$ (bipy $=2,2^{\prime}$ bipyridine) and ascorbic acid showing no decrease in oxidative DNA damage upon addition of selenomethionine (Se). Lanes: 1) $1 \mathrm{~kb}$ ladder; 2) plasmid DNA; 3) DNA + $\mathrm{H}_{2} \mathrm{O}_{2}$; 4) DNA $+\mathrm{H}_{2} \mathrm{O}_{2}+\mathrm{Se}$, 5) DNA $+\mathrm{H}_{2} \mathrm{O}_{2}+$ $\mathrm{Cu}$ (bipy) ${ }_{2}{ }^{+}$/ascorbic acid; 6-10) same as lane 5 with increasing [Se]: $0.1,1,10,100$ and $1000 \mu \mathrm{M}$, respectively.

Table S1. Tabulation of Electrophoresis Results for Selenocystine with $\mathrm{Cu}^{2+}$ /ascorbic acid and $\mathrm{H}_{2} \mathrm{O}_{2}$ (Figure 2) .

\begin{tabular}{|c|c|c|c|c|}
\hline Lane & Concentration $(\mu \mathbf{M})$ & \% Supercoiled DNA & \% Nicked DNA & \% Damage Inhibition \\
\hline 5 & 0 & $8.3 \pm 4.7$ & 91.7 & 0 \\
\hline 6 & 0.001 & $13.2 \pm 9.7$ & 86.8 & $5.4 \pm 8.5$ \\
\hline 7 & 0.1 & $11.9 \pm 6.4$ & 88.1 & $4.1 \pm 2.3$ \\
\hline 9 & 1.0 & $22.7 \pm 8.1$ & 77.3 & $15.9 \pm 6.4$ \\
\hline 10 & 10 & $94.9 \pm 2.5$ & 5.1 & $95.6 \pm 2.3$ \\
\hline
\end{tabular}

${ }^{a}$ All data are reported as the average of three trials; calculated standard deviations are shown. Standard deviations for \% nicked DNA are identical to those for \% supercoiled DNA. 
Table S2. Tabulation of Electrophoresis Results for Selenomethionine with $\mathrm{Cu}^{2+} /$ ascorbic acid and $\mathrm{H}_{2} \mathrm{O}_{2}$ (Figure S1) .

\begin{tabular}{|c|c|c|c|c|}
\hline Lane & Concentration $(\mu \mathbf{M})$ & \% Supercoiled DNA & \% Nicked DNA & \% Damage Inhibition \\
\hline 5 & 0 & $5.2 \pm 3.0$ & 94.8 & 0 \\
\hline 6 & 0.1 & $7.7 \pm 1.0$ & 92.3 & $2.6 \pm 3.6$ \\
\hline 7 & 1 & $6.8 \pm 4.3$ & 93.2 & $1.8 \pm 1.6$ \\
\hline 9 & 10 & $50.8 \pm 7.3$ & 49.2 & $48.5 \pm 8.0$ \\
\hline 10 & 100 & $90.2 \pm 4.7$ & 9.8 & $90.6 \pm 3.7$ \\
\hline
\end{tabular}

${ }^{a}$ All data are reported as the average of three trials; calculated standard deviations are shown. Standard deviations for \% nicked DNA are identical to those for \% supercoiled DNA.

Table S3. Tabulation of Electrophoresis Results for 2-Aminophenyl Diselenide with $\mathrm{Cu}^{2+}$ /ascorbic acid and $\mathrm{H}_{2} \mathrm{O}_{2}($ Figure S2) .

\begin{tabular}{|c|c|c|c|c|}
\hline Lane & Concentration $(\mu \mathbf{M})$ & \% Supercoiled DNA & \% Nicked DNA & \% Damage Inhibition \\
\hline 5 & 0 & $1.1 \pm 1.6$ & 98.9 & 0 \\
\hline 6 & 0.001 & $5.0 \pm 6.8$ & 95.0 & $3.9 \pm 8.0$ \\
\hline 7 & 0.1 & $0.73 \pm 1.1$ & 99.3 & $-0.4 \pm 2.3$ \\
\hline 8 & 1 & $3.8 \pm 3.9$ & 96.2 & $2.8 \pm 4.7$ \\
\hline 10 & 10 & $3.3 \pm 2.7$ & 96.7 & $2.2 \pm 4.1$ \\
\hline
\end{tabular}

${ }^{\mathrm{a}}$ All data are reported as the average of three trials; calculated standard deviations are shown. Standard deviations for \% nicked DNA are identical to those for \% supercoiled DNA.

Table S4. Tabulation of Electrophoresis Results for Selenocystine with $\mathrm{Cu}\left(\right.$ bipy) ${ }_{2}{ }^{2+} /$ ascorbic acid and $\mathrm{H}_{2} \mathrm{O}_{2}$ (Figure 5) .

\begin{tabular}{|c|c|c|c|c|}
\hline Lane & Concentration $(\boldsymbol{\mu M})$ & \% Supercoiled DNA & \% Nicked DNA & \% Damage Inhibition \\
\hline 5 & 0.0 & $14.3 \pm 8.1$ & 85.7 & 0 \\
\hline 6 & 0.001 & $16.5 \pm 9.9$ & 83.5 & $2.8 \pm 4.1$ \\
\hline 7 & 0.1 & $10.4 \pm 3.6$ & 89.6 & $-5.3 \pm 6.5$ \\
\hline 9 & 1.0 & $10.2 \pm 4.4$ & 89.8 & $-5.5 \pm 5.4$ \\
\hline 10 & 10 & $9.9 \pm 5.7$ & 90.1 & $-5.7 \pm 5.9$ \\
\hline
\end{tabular}

${ }^{a}$ All data are reported as the average of three trials; calculated standard deviations are shown. Standard deviations for \% nicked DNA are identical to those for \% supercoiled DNA.

Table S5. Tabulation of Electrophoresis Results for Selenomethionine with $\mathrm{Cu}$ (bipy) ${ }_{2}{ }^{2+} /$ ascorbic acid and $\mathrm{H}_{2} \mathrm{O}_{2}$ (Figure S3) .

\begin{tabular}{|c|c|c|c|c|}
\hline Lane & Concentration $(\boldsymbol{\mu M})$ & \% Supercoiled DNA & \% Nicked DNA & \% Damage Inhibition \\
\hline 5 & 0.0 & $1.7 \pm 2.9$ & 98.3 & 0 \\
\hline 6 & 0.1 & $3.9 \pm 6.7$ & 96.1 & $2.3 \pm 4.0$ \\
\hline 7 & 1 & $3.9 \pm 6.7$ & 96.1 & $2.3 \pm 4.0$ \\
\hline 8 & 10 & $3.9 \pm 6.7$ & 96.1 & $2.3 \pm 4.0$ \\
\hline 10 & 100 & $5.3 \pm 0.0$ & 94.7 & $3.6 \pm 2.9$ \\
\hline
\end{tabular}

${ }^{a}$ All data are reported as the average of three trials; calculated standard deviations are shown. Standard deviations for \% nicked DNA are identical to those for \% supercoiled DNA. 
UV-vis spectra of selenomethionine and 2-aminophenyl diselenide with $\mathrm{Cu}^{+}$. The UVvis spectra for both selenomethionine and 2-aminophenyl diselenide show no additional absorbances when combined with $\mathrm{Cu}^{2+}$ and ascorbic acid.

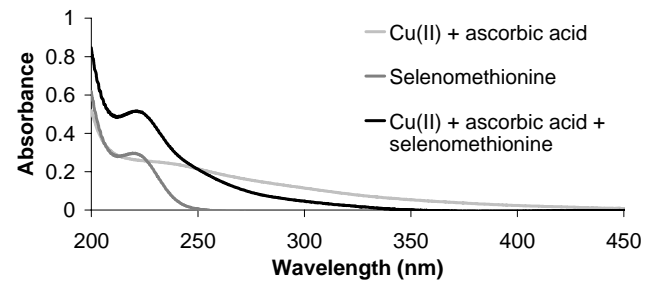

Figure S5. UV-vis spectra of selenomethionine (116 $\mu \mathrm{M}), \mathrm{Cu}^{2+}$ /ascorbic acid $(58 \mu \mathrm{M}$ and $73 \mu \mathrm{M}$, respectively), and $\mathrm{Cu}^{2+}$ /ascorbic acid + selenocystine in water ( $\mathrm{pH} 7$ ). Addition of selenomethionine to ascorbic acid results in no change in the UV-vis absorbance (not shown).

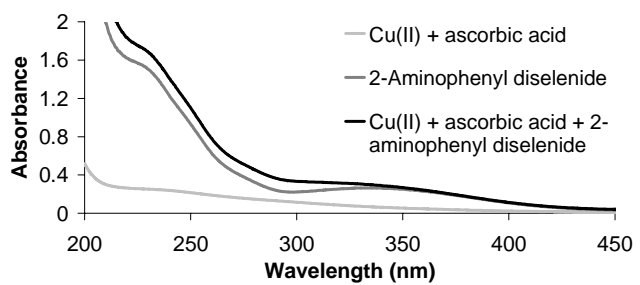

Figure S6. UV-vis spectra of 2-aminophenyl diselenide $(116 \mu \mathrm{M}), \mathrm{Cu}^{2+} /$ ascorbic acid (58 $\mu \mathrm{M}$ and $73 \mu \mathrm{M}$, respectively), and $\mathrm{Cu}^{2+} /$ ascorbic acid + selenocystine in water ( $\mathrm{pH} 7)$. Addition of 2aminophenyl diselenide to ascorbic acid results in no change in the UV-vis absorbance (not shown).

\section{References}

(1) Mareque, A. M.-M.; Faez, J. M.; Chistiaens, L.; Kohnen, S.; Deby, C.; M., H.; M., L.; G., D.-D. Redox Report 2004, 9, 81-87. 